\title{
Effect of Supplementation of Yucca schidigera Extract on Ammonia Gas Emission and Performance of Broiler Chickens
}

\author{
Mahfuj Ullah Patoary ${ }^{1 *}$, Mufazzal Hossain ${ }^{1}$, Mofassara Akter ${ }^{1}$ and Zahir Uddin Rubel ${ }^{2}$ \\ ${ }^{1}$ Department of Animal Nutrition, Genetics \& Breeding, Sher-e-Bangla Agricultural University, Dhaka-1207, Bangladesh \\ ${ }^{2}$ Department of Poultry Science, Sher-e-Bangla Agricultural University, Dhaka-1207, Bangladesh \\ *Corresponding author’s E-mail: mahfujullah.sau@gmail.com, ORCID: 0000-0001-6606-5710
}

Received: 20 Jan. 2020

Accepted: 23 Feb. 2020

\begin{abstract}
The current study was conducted to investigate the efficacy of Yucca extract (YE) on ammonia gas emission from litter, evaluate the production performance, carcass characteristics and economic utility in broiler rearing. A trial of 240 day-old commercial broiler chicks was carried out on littered floor for a period of 28 days. The birds were allocated randomly to 3 treatments and a control group with three replications (20 birds/ replication). Feeding management and rearing condition were same for all the groups, as per standard. YE was mixed with drinking water as treatment as follows: $1 \mathrm{ml}$ YE per 16 liters of drinking water $\left(\mathrm{T}_{1}\right), 1 \mathrm{ml}$ YE per 20 liters of drinking water $\left(\mathrm{T}_{2}\right), 1 \mathrm{ml}$ YE per 24 liters of drinking water $\left(\mathrm{T}_{3}\right)$ and no YE in drinking water i.e control group $\left(\mathrm{T}_{0}\right)$. Ammonia level of Yucca treated groups were significantly $(\mathrm{P}<0.05)$ lower at the $4^{\text {th }}$ week of rearing period than control group. A significant difference $(\mathrm{P}<0.05)$ was noted on body weight, feed consumption, body weight gain and feed conversion ratio value of the birds treated with YE. Carcass percentage and edible portion were significantly $(\mathrm{P}<0.05)$ greater in all treatment groups than control group. Profit per bird and Benefit cost ratio were also higher $(\mathrm{P}<0.05)$ in treatment groups than control group. Among the treatments, the performance of $\mathrm{T}_{2}$ group was better than other groups. This study concluded that application of YE ( $1 \mathrm{ml} / 20$ liters of drinking water) has an important role to reduce ammonia gas emission from broiler litter and increase the birds performance.
\end{abstract}

Keywords: ammonia control, broiler chicken, litter management, Yucca schidigera

\section{INTRODUCTION}

Ammonia in broiler farm is a major concern of this modern poultry industry especially for tropical areas. In the case of poultry, about $50 \%$ of nitrogen $(\mathrm{N})$ content of freshly excreted manure is in the form of uric acid and it can be very quickly transformed into ammonia $\left(\mathrm{NH}_{3}\right)$ by hydrolysis, mineralization, and volatilization (Oenema et al., 2001). Factors that contribute to the formation of $\mathrm{NH}_{3}$ include temperature, moisture, $\mathrm{pH}$, and nitrogen content of the litter or manure. High temperatures increase bacterial activity and also ammonia production, with a 1 to $2^{\circ} \mathrm{C}$ rise having a huge effect on ammonia levels (Visek, 1968). Excess $\mathrm{NH}_{3}$ in broiler house is frequently claimed for growth retardation, poor feed utilization, increase susceptibility to diseases and increase subsequent mortality. Therefore exploring safe and effective ways that control $\mathrm{NH}_{3}$ level in broiler house and increase immunity has become a research priority (Su et al., 2016).

Yucca schidigera (Agavaceae), commonly named yucca is documented as a source of sustenance and herbal drug by native Indians due to its health-promoting activity
(Patel, 2012; Su et al., 2016). The main applications of Yucca powder and juice are in animal nutrition to reduce fecal odors and ammonia, hydrogen sulfide and some other harmful volatile compounds in domestic animal excreta (Cheeke, 2000; Kelly and Kohler, 2003; Gaber, 2006). The former fractions of Yucca Extract (YE) are steroidal saponins and polyphenols (Piacente et al., 2005). The steroidal saponin is the main chemical component of YE, which physically binds ammonia, reducing the level of free ammonia and plays significant role on the improvement of economic traits on broiler chickens (Nazeer et al., 2002). YE has positive effects on the growth rates, feed efficiency, and health in livestock (Colina and Chang, 2001; Duffy et al., 2001; Flaoyen et al., 2002; Kaya et al., 2003; Su et al., 2016; Rezaei et al., 2017).

In present study, the effects of 3 different concentrations of YE on ammonia gas emission, production performance and also carcass characteristics of broiler chickens were investigated with attention to economic utility. 


\section{MATERIALS AND METHODS}

\section{Ethical approval}

The present study was was conducted according ethical rules approved by Sher-e-Bangla Agricultural University, Dhaka, Bangladesh.

\section{Experimental chicks, treatments and management}

A total of 240 day-old broiler chicks of "Cobb-500" strain with $43.2 \pm 0.3 \mathrm{~g}$ average body weight were used in the current study. They were kept in electric brooders equally by maintaining standard brooding protocol. Among them, 180 chicks were distributed randomly in three treatments of Yucca extract providing with drinking water and remaining 60 chicks were distributed as control. Each treatment was divided into three replicates and in each replicate there were 20 birds. The Yucca treated groups were: $1 \mathrm{ml} \mathrm{YE} \mathrm{per} 16$ liters of drinking water $\left(\mathrm{T}_{1}\right)$, $1 \mathrm{ml}$ YE per 20 liters of drinking water $\left(\mathrm{T}_{2}\right), 1 \mathrm{ml}$ YE per 24 liters of drinking water $\left(\mathrm{T}_{3}\right)$ and the group without YE supplementation was control $\left(\mathrm{T}_{0}\right)$. Throughout the period, the chicks were raised in an open-sided broiler house with rice husk-littered floor. Ad libitum feeds and water were provided for rapid growth of broiler chicks up to the end of the four weeks. Nutrient content and feed composition was indicated in table 1 . The chicks were vaccinated with commercial Newcastle disease vaccine (NDV) and Infectious bronchitis (IB) vaccine through eye drops at 4 days and 21 days. The Gumboro vaccines were given through drinking water at day- 9 and day-17 of the experiment respectively.

\section{Collection of ammonia test kit and experimental chemical (Yucca extract)}

To assess ammonia, commercially available Micro Essential pHydrion ${ }^{\mathrm{TM}}$ ammonia meter tester paper was collected. The paper was packaged as a 15 foot roll in a pocket sized plastic dispenser with a polypropylene case and it comes complete with a specially calibrated color chart for matching the ammonia level of the broiler farm. The experimental chemical, Yucca schidigera extract (No$\mathrm{Gas}^{\mathrm{TM}}$ ACI Animal Health) was purchased and it contains saponin steroids and glycocomponents.

\section{Data collection}

Body weight and feed intake were determined weekly. The average of the daily recorded ammonia emission was calculated. Feed conversion ratio (FCR) was calculated as the total feed Intake (FI) divided by weight gain in each replication. Carcass yield of bird was obtained from live weight subtracting blood, feathers, head, shank and inedible viscera. Mortality rate was maintained on a daily basis. Then total survivability of each treatment was calculated as percentage basis.

\section{Economic analysis}

The economic feasibility of $Y$. schidigera supplement for broiler production was estimated on the basis of total expenditure and the return from the sale of live birds (Sahoo et al., 2015). The production cost was calculated by considering the expenses involved in chicks, feed, vaccine and medication, litter materials, disinfectant, electricity, labor and YE. Chicks, disinfectant, vaccine, medicine, litter materials, electricity and labor costs were considered as common costs for both the treated groups and control group. All expenses and income were calculated on the basis of market price (USD) at the time of experimental period. Return was calculated by selling the live birds per $\mathrm{kg}$ weight and profit was computed by subtracting the expenditure. Benefit Cost Ratio (BCR) was calculated by total income divided by total cost of production. Profit per bird (PPB) calculated by total income pee bird subtracting total expenditure per bird.

Table 1. Ingredients and nutrient composition (as-dry matter) of basal diet

\begin{tabular}{lc}
\hline Ingredients & $\begin{array}{c}\text { Composition (\%, unless } \\
\text { otherwise noted) }\end{array}$ \\
\hline Maize & 45.5 \\
Soybean meal (CP 46\%) & 17.0 \\
Wheat flour & 10.0 \\
Bread flour & 5.00 \\
Rice bran & 4.45 \\
Crude palm oil & 3.50 \\
Corn gluten meal (CP 62\%) & 3.60 \\
Distiller dried grains (CP 27\%) & 3.00 \\
Meat bone meal (CP 49\%) & 2.80 \\
Chicken feather meal (CP 79\%) & 2.00 \\
Bone meal (CP 22\%) & 1.50 \\
Lysine & 0.55 \\
Methionine & 0.37 \\
L-threonine & 0.08 \\
Salt & 0.15 \\
Premix ${ }^{1}$ & 0.50 \\
\hline Analysed composition & 3,300 \\
$\quad$ Metabolizable energy (kcal/kg) & 89.6 \\
Dry matter & 21.9 \\
Crude protein & 6.40 \\
Crude fat & 5.62 \\
Crude fiber & 6.39 \\
Ash &
\end{tabular}




\section{Statistical Analysis}

Total data were compiled, tabulated and analyzed in accordance with the objectives of the study. The collected data was subjected to statistical analysis by applying one way ANOVA using Statistical Package for Social Sciences (SPSS- 16.0). Differences between means were tested using Duncan's multiple range test and significance was set at $\mathrm{P}<0.05$.

\section{RESULTS AND DISCUSSION}

\section{Ammonia assessment}

The rate of $\mathrm{NH}_{3}$ emissions from broiler litter against the 28-days of rearing period at different concentration levels of yucca extract had shown in table 2. ANOVA analysis revealed that the average $\mathrm{NH}_{3}$ levels in treated groups and untreated group were insignificant $(\mathrm{P}>0.05)$ in $1^{\text {st }}$ three weeks but it varied statistically $(\mathrm{P}<0.05)$ at $4^{\text {th }}$ week of rearing period. The $\mathrm{T}_{1}$ reduced the rate of $\mathrm{NH}_{3}$ emission to $1 / 2$ of the untreated level, whereas the $T_{2}$ reduced this rate to $2 / 3^{\text {rd }}$ and $\mathrm{T}_{3}$ reduced $1 / 5^{\text {th }}$ of the untreated level. Cabuk et al. (2004) also concluded that the supplementation of Yucca schidigera to the diet reduced $\mathrm{NH}_{3}$ concentration in broiler house. Chepete et al. (2012) reported that when YE was applied to laying-hens, in diets significantly reduced $\mathrm{NH}_{3}$ emission by $44 \%$ and $28 \%$ for the first two days of manure storage. However, Corzo et al. (2007) reported that the supplementation of $100 \mathrm{ppm}$ of YSE and Quillaja saponaria was added in a corn-soybean control diet of broiler chicken, and $\mathrm{NH}_{3}$ emission was not altered compared with control.

Table 2. Effects of Yucca extract on ammonia gas emissions of broiler litter

\begin{tabular}{lcccc}
\hline Treatment & First week & Second week & Third week & Fourth week \\
\hline $\mathrm{T}_{0}$ & $8.37 \pm 0.98$ & $10.23 \pm 1.50$ & $14.97 \pm 3.79$ & $25.87^{\mathrm{a}} \pm 0.73$ \\
$\mathrm{~T}_{1}$ & $6.87 \pm 0.27$ & $8.33 \pm 0.91$ & $9.67 \pm 0.84$ & $11.87^{\mathrm{c}} \pm 0.37$ \\
$\mathrm{~T}_{2}$ & $7.10 \pm 0.30$ & $8.43 \pm 0.58$ & $10.37 \pm 1.02$ & $15.13^{\mathrm{c}} \pm 1.57$ \\
$\mathrm{~T}_{3}$ & $7.33 \pm 0.21$ & $9.37 \pm 1.49$ & $11.53 \pm 0.54$ & $20.17^{\mathrm{b}} \pm 1.53$ \\
\hline
\end{tabular}

Here, $T_{0}=\left(\right.$ Control), $T_{1}=\left(1 \mathrm{ml}\right.$ YE per 16L of drinking water), $T_{2}=(1 \mathrm{ml}$ YE per 20L of drinking water $), \mathrm{T}_{3}=(1 \mathrm{ml}$ YE per $24 \mathrm{~L}$ of drinking water $)$; Different superscripts in a column means significant different $(\mathrm{P}<0.05)$.

\section{Growth performances}

\section{Final Live weight}

The relative final live weight $(\mathrm{g})$ of broiler chickens in the different groups $T_{0}, T_{1}, T_{2}$ and $T_{3}$ were presented in Table 3 and highest value was found in $T_{2}(1632.03 \mathrm{~g})$. Average final live of Yucca treated groups were about 100 $\mathrm{g}$ more than the control group $(1515.60 \mathrm{~g})(\mathrm{P}<0.05)$. Results also demonstrated that the body weights varied among the treatment groups $(\mathrm{P}<0.05)$. Previous researchers stated that the positive effects of dietary supplementation with Yucca products on the growth rates and body weights in different species (Cabuk et al., 2004; Sonia et al., 2005; Sahoo et al., 2015; Su et al., 2016 ; Ahmed, 2018).

\section{Feed intake}

Total feed intake (FI) of different treatment groups and control group have been cataloged in table 3. Result in total FI demonstrated that treatment groups showed significant $(\mathrm{P}<0.05)$ difference than control group. $\mathrm{T}_{2}$ group consumed more feed $(2308.63 \mathrm{~g})$ and $\mathrm{T}_{0}$ (control) group consumed comparatively lower (2296.27 g), whereas $\mathrm{T}_{1}$ and $\mathrm{T}_{3}$ consumed $2306.80 \mathrm{~g}$ and $2306.40 \mathrm{~g}$ respectively. The result also presented that FI of the $1^{\text {st }}$ two weeks (starter phase) significantly $(\mathrm{P}<0.05)$ greater in
Yucca treated groups than control and a reversed trend was recorded at finishing stage (Table 5) that was contradictory to Cabuk et al. (2004) who reported that from 21 to 42 and 42nd day of age, the FC was not significantly different. As Yucca contains saponins that acts biological role as a membrane-permeabilising, immunostimulant and hypocholesterolaemic properties and it has found to have significant affect growth and FI in animals (Das et al., 2012).

\section{Feed conversion ratio}

There was significant difference $(\mathrm{P}<0.05)$ for $\mathrm{FCR}$ among the Yucca treated groups and control group (Table $3)$. The better FCR value was found in $T_{2}$ group (1.45), where control group performed poor (1.56). In $1^{\text {st }}$ two weeks there were insignificant $(\mathrm{P}>0.05)$ difference among the treated groups with control also, but at the last two weeks $\left(3^{\text {rd }}\right.$ and $\left.4^{\text {th }}\right)$ result revealed significant $(\mathrm{P}<0.05)$ difference. Lundeen, (2000), Sonia et al., (2005) and Sahoo et al., (2015) reported that the efficiency of feed utilization was significantly better in Yucca group which led to significantly $(\mathrm{P}<0.05)$ better FCR than control. The broilers exposed to the low concentration of ammonia showed the highest feed efficiency (Shlomo, 2004; Miles et al., 2004) and the study agree with this result as YE affecting ammonia emission. 


\section{Survivability}

There is not any significant difference among the groups in term of survivability (Table 3 ) and the reason might be proper biosecurity management. Some researchers reported that lower survivability percentage was recorded in the control group as compared to the treatment group (Aslan et al., 2005; Sahoo et al., 2015).

\section{Carcass characteristics}

Carcass characteristics of the birds had shown in table 4 and the result demonstrated that eviscerated weight percentage, breast meat and thigh yield were significantly higher in Yucca treated group $(\mathrm{P}<0.05)$ than the control group similar to Sahoo et al. (2015). Thus we also observed, overall yield of edible meat was significantly $(\mathrm{P}<0.05)$ higher in Yucca groups than the control group.

\section{Economics}

The result of economic analysis revealed that Yucca treated groups had significantly $(\mathrm{P}<0.05)$ better profit than control group (Table 5). Total expenditure per bird was slightly high in treated groups than control but was statistically insignificant $(\mathrm{P}>0.05)$. So it can be suggested that application of YE with drinking water may be costeffective management practice to improve shed environment and in turns performance of broiler chicks.

Table 3. Effects of Yucca extract on production performances of broiler chickens.

\begin{tabular}{lccccc}
\hline Treatment & $\begin{array}{c}\text { Final live weight } \\
(\mathrm{g} / \mathrm{bird})\end{array}$ & $\begin{array}{c}\text { Average BWG } \\
(\mathrm{g} / \mathrm{b} \text { bird })\end{array}$ & $\begin{array}{c}\text { Total FI } \\
(\mathrm{g} / \mathrm{bird})\end{array}$ & Final FCR & $\begin{array}{c}\text { Survivability } \\
(\%)\end{array}$ \\
\hline $\mathrm{T}_{0}$ & $1515.60^{\mathrm{c}} \pm 2.47$ & $1472.40^{\mathrm{c}} \pm 2.46$ & $2296.27^{\mathrm{b}} \pm 3.73$ & $1.56^{\mathrm{a}} \pm 0.01$ & $98.33 \pm 1.66$ \\
$\mathrm{~T}_{1}$ & $1621.87^{\mathrm{ab}} \pm 9.76$ & $1575.33^{\mathrm{ab}} \pm 7.48$ & $2306.80^{\mathrm{a}} \pm 1.38$ & $1.46^{\mathrm{b}} \pm 0.07$ & $100.00 \pm 0.00$ \\
$\mathrm{~T}_{2}$ & $1632.03^{\mathrm{a}} \pm 3.40$ & $1588.83^{\mathrm{a}} \pm 3.40$ & $2308.63^{\mathrm{a}} \pm 1.02$ & $1.45^{\mathrm{c}} \pm 0.03$ & $100.00 \pm 0.00$ \\
$\mathrm{~T}_{3}$ & $1607.87^{\mathrm{b}} \pm 5.16$ & $1564.67^{\mathrm{b}} \pm 5.16$ & $2306.40^{\mathrm{a}} \pm 1.15$ & $1.47^{\mathrm{b}} \pm 0.03$ & $100.00 \pm 0.00$ \\
\hline
\end{tabular}

Here, $T_{0}=($ Control$), T_{1}=(1 \mathrm{ml}$ YE per 16L of drinking water $), T_{2}=(1 \mathrm{ml}$ YE per 20L of drinking water $), T_{3}=(1 \mathrm{ml}$ YE per 24L of drinking water $), B W G$ : body weight gain, FI: feed cintake, FCR: feed conversion ratio. Different superscripts in a column means significant different $(\mathrm{P}<0.05)$.

Table 4. Effects of Yucca extract on carcass characteristics of broiler chickens.

\begin{tabular}{lccccc}
\hline Treatment & $\begin{array}{c}* \text { Eviscerated weight } \\
(\%)\end{array}$ & $\begin{array}{c}* \text { Giblet } \\
(\%)\end{array}$ & $\begin{array}{c}* * \text { Breast meat } \\
(\%)\end{array}$ & $\begin{array}{c}* * \text { Drumstick } \\
(\%)\end{array}$ & $\begin{array}{c}* \text { Edible } \\
(\%)\end{array}$ \\
\hline $\mathrm{T}_{0}$ & $59.83^{\mathrm{c}} \pm 1.08$ & $7.40^{\mathrm{a}} \pm 0.57$ & $33.75^{\mathrm{c}} \pm 0.45$ & $16.80 \pm 0.35$ & $67.14^{\mathrm{c}} \pm 0.32$ \\
$\mathrm{~T}_{1}$ & $65.82^{\mathrm{b}} \pm 0.40$ & $6.50^{\mathrm{ab}} \pm 0.26$ & $35.09^{\mathrm{bc}} \pm 0.34$ & $17.00 \pm 0.25$ & $72.07^{\mathrm{b}} \pm 0.34$ \\
$\mathrm{~T}_{2}$ & $68.39^{\mathrm{a}} \pm 0.56$ & $5.51^{\mathrm{b}} \pm 0.28$ & $37.14^{\mathrm{a}} \pm 0.58$ & $17.17 \pm 0.38$ & $73.64^{\mathrm{a}} \pm 0.33$ \\
$\mathrm{~T}_{3}$ & $67.05^{\mathrm{ab}} \pm 0.70$ & $6.11^{\mathrm{ab}} \pm 0.46$ & $35.67^{\mathrm{b}} \pm 0.33$ & $17.13 \pm 0.31$ & $72.86^{\mathrm{ab}} \pm 0.69$ \\
\hline
\end{tabular}

Here, $T_{0}=($ Control $), T_{1}=(1 \mathrm{ml}$ Yucca extract per 16L of drinking water $), T_{2}=(1 \mathrm{ml}$ Yucca extract per 20L of drinking water $), T_{3}=(1 \mathrm{ml}$ Yucca extract per 24L of drinking water), *percentage of body weight, **percentage of eviscerated weight. Different superscripts in a column means significant different $(\mathrm{P}<0.05)$.

Table 5. Effects of Yucca extract on economic aspects of broiler chicken farming.

\begin{tabular}{lcccc}
\hline \multirow{2}{*}{ Parameter } & \multicolumn{4}{c}{ Treatment } \\
\cline { 2 - 5 } & $\mathbf{T}_{\mathbf{0}}$ & $\mathbf{T}_{\mathbf{1}}$ & $\mathbf{T}_{\mathbf{2}}$ & $\mathbf{T}_{\mathbf{3}}$ \\
\hline Feed cost (USD) per bird & $1.16 \pm 0.29$ & $1.17 \pm 0.28$ & $1.18 \pm 0.21$ & $1.17 \pm 0.42$ \\
Cost of Yucca extract (USD) per bird & 0 & 0.021 & 0.017 & 0.014 \\
Common expenditure (USD) per bird & 0.81 & 0.82 & 0.81 & 0.82 \\
Total Expenditure (USD) per bird & $1.98 \pm 0.30$ & $2.01 \pm 0.43$ & $2.01 \pm 0.22$ & $1.99 \pm 0.27$ \\
Receipt per bird when sold & $2.35^{\mathrm{c}} \pm 0.32$ & $2.50^{\mathrm{b}} \pm 1.2$ & $2.53^{\mathrm{a}} \pm 0.44$ & $2.51^{\mathrm{b}} \pm 0.67$ \\
(1.55 USD/ Kg Live weight) & $0.39^{\mathrm{c}} \pm 0.60$ & $0.49^{\mathrm{ab}} \pm 0.97$ & $0.52^{\mathrm{a}} \pm 0.66$ & $0.48^{\mathrm{b}} \pm 1.07$ \\
Profit per bird (USD) & $1.18^{\mathrm{b}} \pm 0.03$ & $1.24^{\mathrm{a}} \pm 0.06$ & $1.25^{\mathrm{a}} \pm 0.03$ & $1.24^{\mathrm{a}} \pm 0.01$ \\
Benefit cost ratio & $(10.03$
\end{tabular}

Here, $T_{0}=($ Control $), T_{1}=(1 \mathrm{ml} \mathrm{YE} \mathrm{per} \mathrm{16L} \mathrm{of} \mathrm{drinking} \mathrm{water}), T_{2}=(1 \mathrm{ml} \mathrm{YE} \mathrm{per} \mathrm{20L} \mathrm{of} \mathrm{drinking} \mathrm{water}), T_{3}=(1 \mathrm{ml} \mathrm{YE} \mathrm{per} \mathrm{24L} \mathrm{of} \mathrm{drinking} \mathrm{water).} \mathrm{Different}$ superscripts in a column means significant different $(\mathrm{P}<0.05)$. 


\section{CONCLUSION}

Analyzing the above research findings, this study suggested that the $1 \mathrm{ml}$ of Yucca schidigera plant extract with $20 \mathrm{~L}$ of drinking water may be used to minimize the ammonia gas emission, for better production performance, to improve carcass quality and more economic benefit in broiler rearing. Yucca schidigera plant naturally not found in many areas of the world but the extract might be commercially available to other countries. The study therefore recommends for hematological parameters on birds immunity. Hence, it could be safely used in broiler rearing for higher economical return without any adversity.

\section{DECLARATIONS}

\section{Acknowledgement}

We would like to thank Ministry of Science and Technology (MOST) for financially supporting and the Sher-e-Bangla Agricultural University, who provided us with the opportunity to conduct this study.

\section{Author's contribution}

Mahfuj Ullah Patoary and Mufazzal Hossain conducted the research, prepared data and performed statistical analysis. Mofassara Akter and Zahir Uddin Rubel wrote the article. All authors checked and confirmed the final form of article.

\section{Competing interests}

The authors declared that they have no competing interests.

\section{Consent to publish}

All authors informed their consent prior to inclusion in the study.

\section{REFERENCES}

Ahmed A (2018). Effect of adding local Yucca aloifolia powder in diet in productive performance of quail. Conference: $8^{\text {th }}$ International Conference for Sustainable Agriculture Development. Egypt. Available at: https://www.researchgate.net/publication/325871084

Aslan R, Dundar Y, Eryavuz A, Bulbul A, Kucukkurt I, Fidan AF and Akinci Z (2005). Effects of various quantities of Yucca schidigera powder (Deodorase) added to diets on the performance, some hematological and biochemical blood parameters, and total antioxidant capacity of laying hens. Revue De Medecine Veterinaire, 156: 350-355. Available at: https://www.revmedvet.com/2005/RMV156_350_355.pdf

Cabuk M, Alcicek A, Bozkurt M and Akkan S (2004). Effect of Yucca schidigera and Natural Zeolite on Broiler Performance. International Journal of Poultry Science, 3(10): 651-654. DOI: http://dx.doi.org/10.3923/ijps.2004.651.654
Cheeke PR (2000) Actual and Potential Applications of Yucca Schidigera and Quillaja Saponaria Saponins in Human and Animal Nutrition. In: Oleszek W., Marston A. (eds) Saponins in food, feedstuffs and medicinal plants. proceedings of the phythochemical society of Europe, 45. DOI: https://doi.org/10.1007/978-94-015-9339-7_25

Chepete HJ, Xin H, Mendes LB, Li H and Bailey TB (2012). Ammonia emission and performance of laying hens as affected by different dosages of Yucca schidigera in the diet. Journal of Applied Poultry Research, 21(3): 522-530. DOI: https://doi.org/10.3382/japr.201100420

Colina JJ and Chang EJ (2001). Dietary manipulation to reduce aerial ammonia concentrations in nursery pig facilities. Journal of Animal Science, 79: 3096-3103. DOI: https://doi.org/10.2527/2001.79123096x

Corzo A, Kidd MT, Miles DM, Dozier WA and Cheeke PR (2007). Yucca schidigera and Quillaja saponaria supplementation in broiler diets [abstract]. International Poultry Scientific Forum, p. 64. Available https://www.ars.usda.gov/research/publications/publication/?seqNo $115=201720$

Das TK, Banerjee D, Chakraborty D, Pakhira MC, Shrivastava B and Kuhad RC (2012). Saponin: Role in Animal system. Veterinary World, 5(4): 248-254. DOI: https://doi.org/10.5455/vetworld.2012.248-254

Duffy CF, Killeen GF, Connolly CD and Power RF (2001). Effects of dietary supplementation with Yucca schidigera Roezl ex Ortgies and its saponin and non-saponin fractions on rat metabolism. Journal of Agricultural and Food Chemistry, 49: 3408-3413. DOI: https://doi.org/10.1021/jf010149+

Flaoyen A, Wilkins AL and Sandvik M (2002). Ruminal metabolism in sheep of saponins from Yucca schidigera. Veterinary Research $\begin{array}{lll}\text { Communications. 26(2):159-69. } & \text { DOI: }\end{array}$ https://doi.org/10.1023/A:1014051803104

Gaber MM (2006). The effects of plant-protein based diets supplemented with Yucca on growth, digestibility, and chemical composition of Nile Tilapia (Oreochromis niloticus, L) fingerlings. Journal of the World Aquaculture Society, 37: 74-81. DOI: https://doi.org/10.1111/j.1749-7345.2006.00008.x

Kaya S, Erdogan Z and Erdogan S (2003). Effect of different dietary levels of Yucca schidigera powder on the performance, blood parameters and egg yolk cholesterol of laying quails. Journal of Veterinary Medicine Series A, 50(1): 14-17. DOI: https://doi.org/10.1046/j.1439-0442.2003.00487.x

Kelly AM and Kohler CC (2003). Effects of Yucca schidigera extract on growth, nitrogen retention, ammonia excretion, and toxicity in channel catfish Ictalurus punctatus and hybrid tilapia $\mathrm{O}$. mossambicus $\times$ O. niloticus. Journal of the World Aquaculture Society, 34: 156-161. DOI: https://doi.org/10.1111/j.17497345.2003.tb00052.x

Miles DM, Butcher NH, Branton SL and Lott BD (2004). atmospheric ammonia is detrimental to the performance of modern commercial broilers. Poultry Science, 83(10): 1650-1654. DOI: https://doi.org/10.1093/ps/83.10.1650

Nazeer MS, Pasha TN, Shahid A and Ali Z (2002). Effect of Yucca saponin on urease activity and development of ascites in broiler chickens. International Journal of Poultry Science, 1(6): 174-178. DOI: http://dx.doi.org/10.3923/ijps.2002.174.178

Oenema O, Bannink A, Sommer SG and Velthof GL (2001), Gaseous nitrogen emissions from livestock farming systems. Nitrogen in the environment: sources, problems, and management. Elsevier, Amsterdam, pp. 255-289. Link: https://research.wur.nl/en/publications/gaseous-nitrogen-emissionsfrom-livestock-farming-systems-2 
Panetta DM, Powers WJ, Xin H, Kerr BJ and Stalder KJ (2006). Nitrogen excretion and ammonia emissions from pigs fed modified diets. Journal of Environmental Quality, 35(4): 1297-1308. DOI: https://doi.org/10.2134/jeq2005.0411

Patel S (2012). Yucca: A medicinally significant genus with manifold therapeutic attributes. Natural Products and Bioprospecting, 2(6): 231-234. DOI: https://doi.org/10.1007/s13659-012-0090-4

Piacente S, Pizza1 C and Oleszek W (2005). Saponins and phenolics of Yucca schidigera Roezl: Chemistry and bioactivity. Phytochemistry Reviews, 4(2-3): 177-190. DOI: https://doi.org/10.1007/s11101-005-1234-5

Rezaei R, Lei J and Wu G (2017). Dietary supplementation with Yucca schidigera extract alleviates heat stress-induced growth restriction in chickens. Journal of Animal Science, 95(4): 370-371. DOI: https://doi.org/10.2527/asasann.2017.866

Sahoo SP, Kaur D, Sethi APS, Sharma A and Chandra M (2015). Evaluation of Yucca schidigera extract as feed additive on performance of broiler chicks in winter season. Veterinary World, 8(4): 556-560. DOI: http://doi.org/10.14202/vetworld.2015.556-560

Santoso B, Mwenya B, Sar C and Takahashi J (2006). Ruminal fermentation and nitrogen metabolism in sheep fed a silage-based diet supplemented with Yucca schidigera or Y. schidigera and nisin. Animal Feed Science and Technology, 129(3): 187-195. DOI: https://doi.org/10.1016/j.anifeedsci.2006.01.001

Shlomo Y (2004). Ammonia affects performance and thermoregulation of male broiler chickens. Animal Research, 53: 289-293. DOI: https://doi.org/10.1051/animres:2004015

Su JL, Shi BL, Zhang PF, Sun DS, Li TY and Yan SM (2016). Effects of Yucca extract on feed efficiency, immune and antioxidative functions in broilers. Brazilian Archives of Biology and Technology, 59: e16150035. DOI: https://doi.org/10.1590/16784324-2016150035

Visek WJ (1968). Some aspects of ammonia toxicity inanimal cells. Journal of Dairy Science, 51: 286. DOI: https://doi.org/10.3168/jds.S0022-0302(68)86976-0 